\title{
Salivary mucoepidermoid carcinoma, auclair vs brandwein grading system: A histopathological comparative study
}

\author{
Omar I. Ahmed (1), Lehadh M. Al-Azzawi (2) \\ Article DOI: https://doi.org/10.26477/jbcd.v32i3.2895
}

\begin{abstract}
Background: The grading systems of salivary mucoepidermoid carcinoma depend on different histologic and morphologic features. The aim of this study was to compare between Auclair and Brandwein systems according to their histologic criteria, and the type of cell predominant.

Materials and Methods: Twenty-one case included hematoxylin-eosin (H\&E) stained tissue slides that were diagnosed as MEC, originally categorized into low and high grade type regardless of the grading system, have meticulously undergone histopathologic review. The sample was graded according to criteria owing to Auclair and Brandwein methods. The predominant type of cells was determined by microscopic examination according to grade of tumor.

Results: Regarding the Auclair method, 10 cases (47.6\%) were low grade tumor, 11 cases $(52.2 \%)$ were high grade type and none of them were intermediate type. By using Brandwein system for the same sample, 4 cases $(19 \%)$ were low grade, 13 cases (61\%) were a high grade tumor, and 4 cases $(19 \%)$ were intermediate type. Even though, for both systems more than $35 \%$ of cases were predominated with epidermoid cells, and $<15 \%$ showed mucous and intermediate cell predominance for each, whereas $>30 \%$ were exhibited a mixed type of tumor cells. However, there was a significant correlation between the grading systems applied and the type of cell predominance ( $p$-value $<0.05$ ).

Conclusion: The number of cases distributed according to Brandwein system was increased as the level of histologic grade being raised, and the type of cells, which are relatively predominant, may be valuable in determining the histologic grade of tumors.

Keyword: Mucoepidermoid carcinoma (MEC), Auclair system, Brandwein system. (Received: 2/10/2017; Accepted: 20/11/2017).
\end{abstract}

\section{INTRODUCTION}

Salivary gland carcinomas (SGCs) are rare malignant tumors with overall incidence ranged internationally from $0.4-2.6$ cases $/ 1000,000$ population per year and comprise only 3-5\% of all malignant neoplasms of head and neck. ${ }^{(1)}$ These tumors are morphologically diverse and as yet, at least 24 different types were recognized by World Health Organization (WHO). ${ }^{(2)}$ Mucoepidermoid carcinoma (MEC) is one of the highlighted entities of salivary gland malignancy and is histologically composed of mixture of mucous-producing cells, intermediate cells and epidermoid (squamous) cells; in different proportions which usually determine the grade of tumor, in addition to clear cells, oncocytic and columnar cells. ${ }^{(3)}$ Regarding their histopathological diagnoses, MECs can be classified into low-, intermediate-, and high-grade subtypes according to the amount of cystic components; degree of cellular and nuclear atypia; and relative numbers of different cell types. ${ }^{(4)}$

In fact, the most popular grading systems of MEC are: The Armed force institution of pathology (AFIP) suggested by Auclair et al.(1991) and Brandwein et al.(2001).

(1) Assistant lecturer, Department of Dentistry, Bilad Al Rafidain University, Diyala -Iraq.

(2) Assistant Professor, Department of Dentistry, Al-Hikma

University College, Baghdad -Iraq.

Corresponding author, okok54321okok@gmail.com
These systems are designated as 3-levels and exhibit best reproducibility among the pathologists, although the criteria proposed for such systems are still under debate..$^{(5,6)}$

Both systems are custom-built and numericallybased schemes with different points reflecting the quantitative values assigned for each histologic parameter. ${ }^{(7-9)}$ However, the histologic criteria in both systems are weighted according to the magnitude of its significance with ascending point scores equivalent to a higher grade. ${ }^{(10)}$

The grading stystems of MECs have revealed some flaws, unlikely they are troubling, timeconsuming and somewhat the histologic criteria are not well-defined. ${ }^{(5,6,11)}$ As noted, all systems appeared to be a good prognostic indicator even independent on TNM staging, as well as the way of correlation between each syatem and clinical outcome is quite variable and several studies indicated that the Brandwein system appears to 'up-grade' tumors, whereas the AFIP system appears to 'down-grade' tumors. Accordingly, the proper treatment and the prediction of patient's outcome may be more difficult due to these variations. ${ }^{(1)}$ This study aims to compare between Auclair and Brandwein systems according to their histologic criteria, and the type of cell predominant. 


\section{MATERIALS AND METHODS}

The materials of this study consisted of twentyone formalin-fixed, paraffin-embedded (FFPE) specimens of salivary MEC, all collected from archives of the Oral Diagnosis Department /college of Dentistry/University of Baghdad, and from the Department of Specialized Surgery/Al-Shaheed Ghazi Hospital/ Baghdad. The clinical information was obtained from the patient's medical records, including age, gender, tumor site and nodal involvement. All the cases were histologically diagnosed by two specialists, pathologists, who were both blinded from the patients' clinical data.

Approximately $4 \mu \mathrm{m}$ thick sections were prepared and stained with hematoxylin and eosin (H\&E) stain to confirm the diagnosis. All tumors were reviewed and graded according to the criteria of the point-based methods for both Auclair and Brandwein, respectively, (Table 1) and (Figure.1). Eventually, comparison of the two grading systems has been achieved according to their own histologic parameters. The correlation between cell types predominance and the grade of tumor was statistically analyzed by using The chi-square test.

Table 1: Comparison of the Two Point -based Grading System of Mucoepidermoid Carcinoma.

\begin{tabular}{|c|c|c|c|}
\hline AFIP system & Points & Brandwein system & points \\
\hline Intracystic component $<20 \%$ & 2 & Intracystic component $<25 \%$ & 2 \\
\hline Neural invasion present & 2 & Tumor invades in small nests and islands & 2 \\
\hline Necrosis present & 3 & Pronounced nuclear atypia & 2 \\
\hline $\begin{array}{l}\text { Mitosis ( } 4 \text { or more per } 10 \\
\text { HPF }^{*} \text { ) }\end{array}$ & 3 & Lymphatic and/or vascular invasion & 3 \\
\hline Anaplasia & 4 & Bony invasion & 3 \\
\hline Grade & Score & \multirow[t]{2}{*}{ More than 4 mitoses per $10 \mathrm{HPF}$} & \multirow[t]{2}{*}{3} \\
\hline Low grade & $0-4$ & & \\
\hline \multirow[t]{2}{*}{ Intermediate grade } & \multirow[t]{2}{*}{$5-6$} & Perineural spread & 3 \\
\hline & & Necrosis & 3 \\
\hline \multirow[t]{4}{*}{ High grade } & \multirow[t]{4}{*}{$7-14$} & Grade & Score \\
\hline & & Grade I & 0 \\
\hline & & Grade II & $2-3$ \\
\hline & & Grade III & $>4$ \\
\hline
\end{tabular}

* High power field

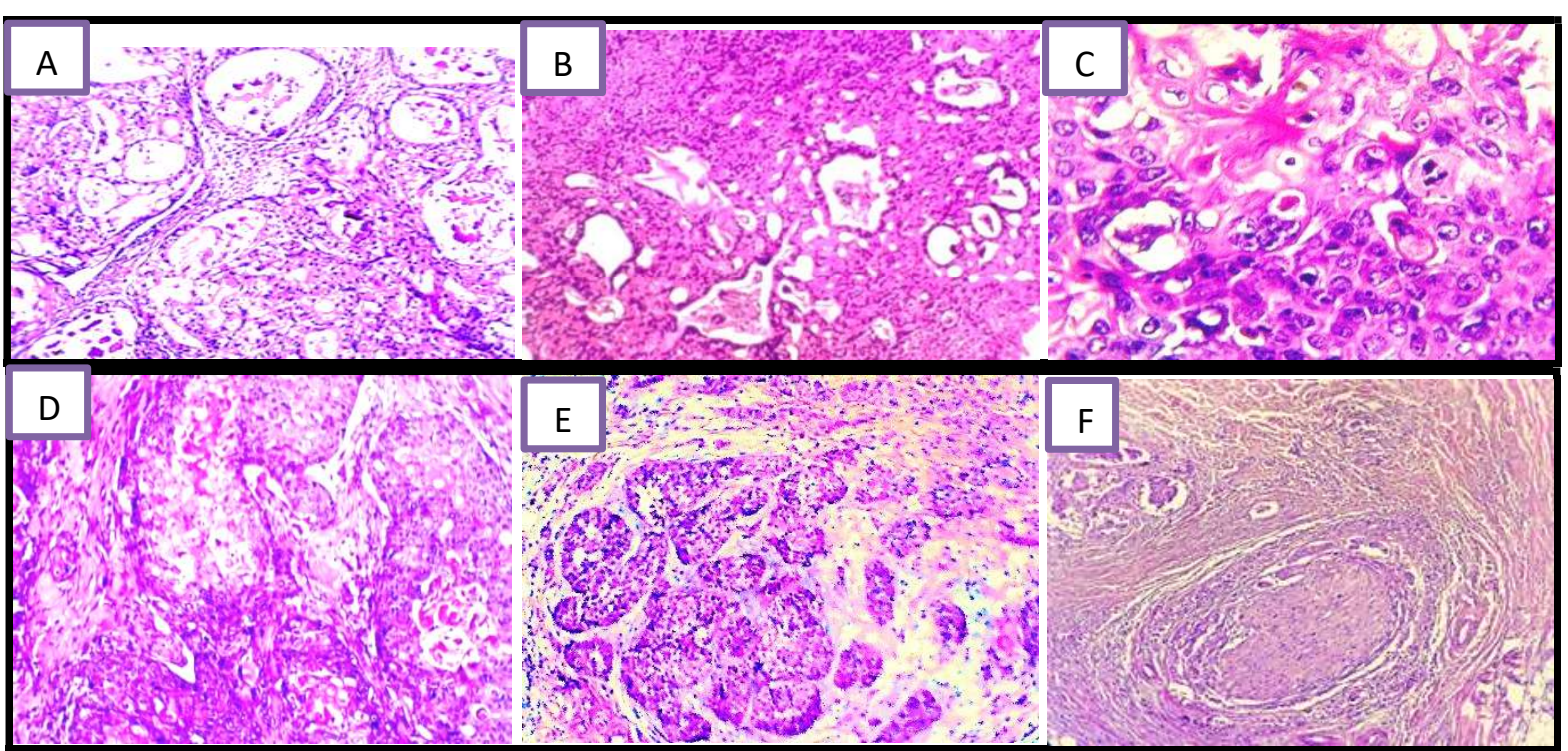

Figure 1: (H\&E) stained sections of salivary MEC, A, low grade tumor with macrocystic spaces, lined with mucous, squamous cells and intermediate cells, and containing mucous secretion (10x). B, intermediate grade tumor with fewer cystic component, more solid area with predominance of intermediate cells (10x). C, High grade MEC showed more nuclear atypia and mitosis $>4$ per $10 \mathrm{HPF},(40 \mathrm{x})$. D, demonstrate foci of necrosis with lymphocyte infiltration (20x). E, Aggressive pattern of tumor infiltration; tumor is invaded by a small islands of tumor cells (leading-edege infiltration), which are the defining feature of Grade II and III, according to Brandwein system (20x). F, High grade tumor with perineural invasion, tumor cells invading the soft tissue surrounding the involved nerve (10x). 


\section{RESULTS}

Altogether, 21 cases of MEC were reviewed according to The Auclair grading system. The cases were classified as follow: $47.6 \%(10 / 21)$ were low grade tumors and $52 \%(11 / 21)$ were high grade type, whereas no case in this series was an intermediate type (Table 2). Regarding The Brandwein system, the cases were $19 \%(4 / 21)$ for grade I tumor, whereas grade II and III tumors constituted about 19\% (4/21) and 61.9\% (13/21), respectively (Table 3 ). Regarding the type of cells that mainly predominated in the tumor, the distribution of cases was as follows:

Table2: Case Distribution according to The Auclair Grading System.

\begin{tabular}{|l|c|c|c|}
\hline \multicolumn{1}{|c|}{ Criteria } & Points & Score & $\begin{array}{c}\text { No. } \\
\text { of } \\
\text { cases }\end{array}$ \\
\hline $\begin{array}{l}\text { Intracystic } \\
\text { component }<20 \%\end{array}$ & 2 & $\begin{array}{c}<20 \% \\
>20 \%\end{array}$ & $\begin{array}{c}12 \\
9\end{array}$ \\
\hline Neural invasion & 2 & $\begin{array}{c}-\mathrm{ve} \\
+\mathrm{ve}\end{array}$ & $\begin{array}{c}17 \\
4\end{array}$ \\
\hline Necrosis & 3 & $\begin{array}{l}-\mathrm{ve} \\
+\mathrm{ve}\end{array}$ & 10 \\
& 3 & $\begin{array}{l}-\mathrm{ve} \\
+\mathrm{ve}\end{array}$ & $\begin{array}{c}9 \\
12\end{array}$ \\
\hline Four or more \\
mitosis per10 HPF & & $\begin{array}{l}-\mathrm{ve} \\
+\mathrm{ve}\end{array}$ & $\begin{array}{c}8 \\
13\end{array}$ \\
\hline Anaplasia & 4 & \multicolumn{2}{|c|}{ Score } \\
\hline Grade & $\begin{array}{l}\text { Total } \\
\text { points }\end{array}$ & $0-4$ & $10(47.6 \%)$ \\
\hline Low & $5-6$ & \multicolumn{2}{|c|}{$0(0.0 \%)$} \\
\hline Intermediate & $7-14$ & $11(52.4 \%)$ \\
\hline High & \multicolumn{3}{|c|}{} \\
\hline
\end{tabular}

$14.2 \%, 38 \%$ and $14.2 \%$ of mucous-producing cells, squamous cells and intermediate cells predominate, respectively, and the remaining $33.3 \%$ were a mixed type of cells (Table 4 ) and (Fig 2). It was found that the type of tumor cell predominant was significantly correlated with both systems, according to Chi square test ( $p$-value for Auclair and Brandwein systems was 0.006 and 0.029 , respectively).

Table 3: Case Distribution according to Brandwein Grading System.

\begin{tabular}{|c|c|c|c|}
\hline Criteria & $\begin{array}{c}\text { Point } \\
\text { S }\end{array}$ & Score & $\begin{array}{l}\text { No. of } \\
\text { cases }\end{array}$ \\
\hline $\begin{array}{l}\text { Intracystic components } \\
<25 \%\end{array}$ & 2 & $\begin{array}{l}<25 \% \\
>25 \%\end{array}$ & $\begin{array}{c}12 \\
9\end{array}$ \\
\hline $\begin{array}{l}\text { Pronounced nuclear } \\
\text { atypia }\end{array}$ & 2 & $\begin{array}{l}\text {-ve } \\
+\mathrm{ve}\end{array}$ & $\begin{array}{c}8 \\
13\end{array}$ \\
\hline $\begin{array}{l}\text { Tumor front invades in } \\
\text { small nests and island }\end{array}$ & 2 & $\begin{array}{l}\text {-ve } \\
+\mathrm{ve}\end{array}$ & $\begin{array}{c}7 \\
14\end{array}$ \\
\hline $\begin{array}{l}\text { Lymphatic\&vascular } \\
\text { invasion }\end{array}$ & 3 & $\begin{array}{l}\text {-ve } \\
+\mathrm{ve}\end{array}$ & $\begin{array}{c}21 \\
0\end{array}$ \\
\hline Bony invasion & 3 & $\begin{array}{l}\text {-ve } \\
+ \text { ve }\end{array}$ & $\begin{array}{c}20 \\
1\end{array}$ \\
\hline $\begin{array}{l}\text { Greater than } 4 \text { mitosis } \\
\text { per } 10 \mathrm{HPF}\end{array}$ & 3 & $\begin{array}{l}\text {-ve } \\
+\mathrm{ve}\end{array}$ & $\begin{array}{c}9 \\
12 \\
\end{array}$ \\
\hline Perineural spread & 3 & $\begin{array}{l}\text {-ve } \\
+ \text { ve }\end{array}$ & $\begin{array}{c}17 \\
4\end{array}$ \\
\hline Necrosis & 3 & $\begin{array}{l}\text {-ve } \\
+\mathrm{ve}\end{array}$ & $\begin{array}{l}10 \\
11\end{array}$ \\
\hline Grade & Total & \multicolumn{2}{|c|}{ Grade of study } \\
\hline$I$ & 0 & \multicolumn{2}{|c|}{$4(19 \%)$} \\
\hline$I I$ & $2-3$ & \multicolumn{2}{|c|}{$4(19 \%)$} \\
\hline$I I I$ & $>4$ & \multicolumn{2}{|c|}{$13(61.9 \%)$} \\
\hline
\end{tabular}

Table 4: Cases distribution according to predominated type of tumor cells.

\begin{tabular}{|c|c|c|c|c|c|c|}
\hline \multirow{2}{*}{\multicolumn{2}{|c|}{$\begin{array}{l}\text { A: Auclair grade } \\
\text { B: Brandwein grade }\end{array}$}} & \multicolumn{5}{|c|}{ Predominate cells } \\
\hline & & Mucous & Squamous & Intermediate & Mixed & Total \\
\hline \multirow[t]{2}{*}{ Low } & $\mathbf{A}$ & $\begin{array}{c}3 \\
(14.2 \%)\end{array}$ & & $\begin{array}{c}2 \\
(9.5 \%)\end{array}$ & $\begin{array}{c}5 \\
(23.8 \%)\end{array}$ & $\begin{array}{c}10 \\
(47.6 \%)\end{array}$ \\
\hline & B & $\begin{array}{c}2 \\
(9.5 \%) \\
\end{array}$ & & & $\begin{array}{c}2 \\
(9.5 \%) \\
\end{array}$ & $\begin{array}{c}4 \\
(19.0 \%) \\
\end{array}$ \\
\hline \multirow[t]{2}{*}{ Intermediate } & $\mathbf{A}$ & & & & & \\
\hline & B & & & $\begin{array}{c}1 \\
(4.7 \%)\end{array}$ & $\begin{array}{c}3 \\
(14.2 \%) \\
\end{array}$ & $\begin{array}{c}4 \\
(19.0 \%) \\
\end{array}$ \\
\hline \multirow[t]{2}{*}{ High } & $\mathbf{A}$ & & $\begin{array}{c}8 \\
(38.0 \%) \\
\end{array}$ & $\begin{array}{c}1 \\
(9.5 \%) \\
\end{array}$ & $\begin{array}{c}2 \\
(9.5 \%) \\
\end{array}$ & $\begin{array}{c}11 \\
(52.3 \%) \\
\end{array}$ \\
\hline & B & $(9.5 \%)$ & $\begin{array}{c}8 \\
(38.0 \%)\end{array}$ & $\begin{array}{c}2 \\
(9.5 \%)\end{array}$ & $\begin{array}{c}2 \\
(9.5 \%)\end{array}$ & $\begin{array}{c}13 \\
(61 . \%)\end{array}$ \\
\hline \multirow[b]{3}{*}{ Total } & \multirow[t]{2}{*}{$\mathbf{A}$} & $\begin{array}{c}3 \\
(142 \%)\end{array}$ & $\begin{array}{c}8 \\
(38.0 \%)\end{array}$ & $\begin{array}{c}3 \\
(14.2 \%)\end{array}$ & $\begin{array}{c}7 \\
(33.3 \%)\end{array}$ & 21 \\
\hline & & $(14.2 \%)$ & & & $(55.5 \%)$ & \\
\hline & B & $\begin{array}{c}3 \\
(14.2 \%)\end{array}$ & $\begin{array}{c}8 \\
(38.0 \%)\end{array}$ & $\begin{array}{c}3 \\
(14.2 \%)\end{array}$ & $\begin{array}{c}7 \\
(33.3 \%)\end{array}$ & 21 \\
\hline Test & \multicolumn{6}{|c|}{$\begin{array}{l}\text { Chi square test for predominant cells with Auclair/p value }=0.006 \\
\text { Chi square test for predominant cells with Brandwein /p value }=0.029\end{array}$} \\
\hline
\end{tabular}




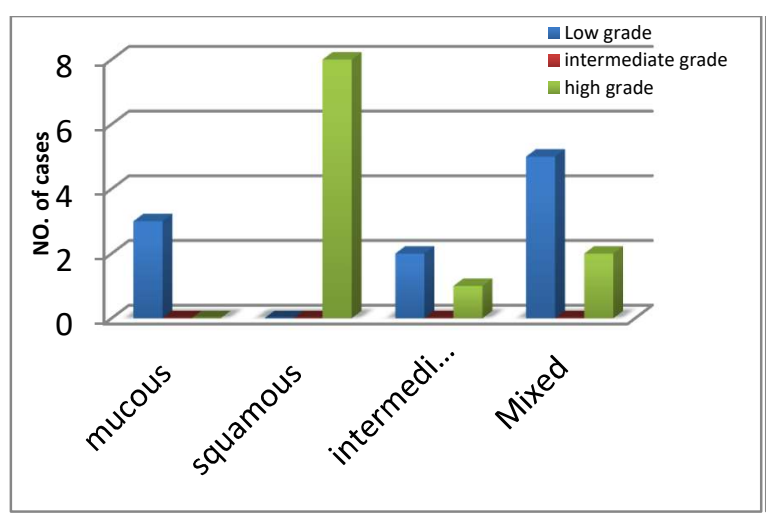

(A)

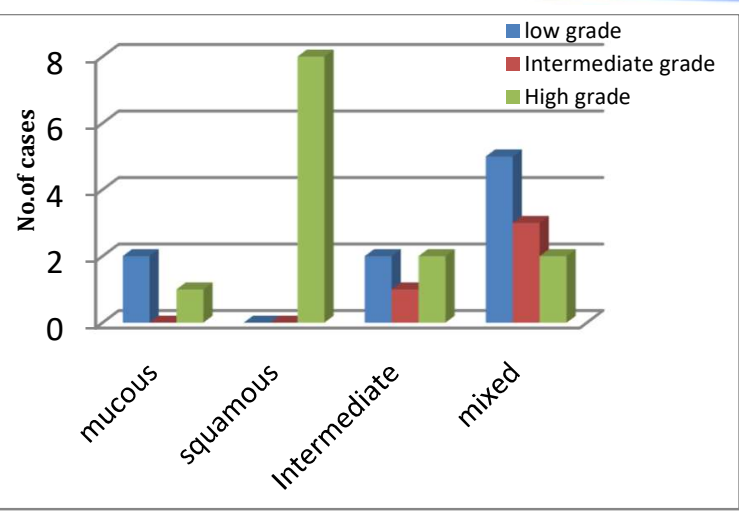

(B)

Figure 2: Distribution of cases, according to type of cell predominance, with regard to (A) Auclair (B) Brandwein system.

\section{DISCUSSION}

Salivary gland neoplasms are relatively rare and a morphologically diverse group of lesions. Diagnosis based on (H\&E) stained sections remains the gold standard in salivary gland pathology. ${ }^{(14)}$ In the present study, the cases were categorized into low, intermediate and high grade according to criteria of Auclair and Brandwein schemes. In general, the distribution of the number of MEC cases, in most epidemiologic studies, was inversely related to the level of the histologic grade. ${ }^{(15,16,17)}$ In this study, according to Auclair system, we found that little difference, concerning cases distribution between low and high grade tumors (Table 2). Correspondingly, from data of (Table 3) which presents the distribution of cases according to Brandwein system, it is apparent that the number of distributed cases is increased as the level of histologic grade being raised and this in accordance with other documented reports. ${ }^{(18,19,20)}$ MECs are histologically heterogeneous tumors with various degrees of cells differentiation, including mainly mucous-secretory cells, small basaloid type (intermediate) cells and epidermoid (squamous) cells, in addition to other cell types, and usually these cells may be proportionally present in the tumor or exhibiting a predominant sorts. ${ }^{(20,21)}$ In this study, we found that the cell types predominance were significantly correlated with histologic grading systems ( $\mathrm{p}$-value appeared to be $<0.05$ ) and more squamous cell count were detected in a high grade type, irrespective to the grading system, as illustrated in (Figure 2), thus this was in agreement with results from other researches. ${ }^{(3,20,21)}$

Finally, the results of this study confirm previous observations that there is a difference in cases distribution relevant to the level of histologic grade of tumor which is usually determined by the grading system used, or by counting type of cells that relatively or predominantly constituted the bulk of tumor.

\section{CONCLUSION}

According to the criteria proposed by Brandwein method, which has been approved in this study, the number of cases was increased as the level of histologic grade being raised. Regarding the predominant cells in the tumor, this feature was relatively valuable in determining the histologic grade of the mucoepidermiod carcinoma regardless of the grading system that is applied.

\section{Conflict of interest: None.}

\section{REFERENCES}

1. Eveson JW, Auclair PL, Gnepp DR. Tumors of the salivary glands: introduction. In: Barnes EL, Eveson JW, Reichart P, Sidransky D, editors. World Health Organization classification of tumours: pathology \& genetics. Head and neck tumours. Lyon: IARCPress; 2005. p. 221-2.

2. Luukkaa H. Salivary gland cancer in filand incedence, histologic distribution ,outcome and prognostic factors. Acadimic dissertation, University of Turku . Filand, 2010. p 53.

3. Luna MA. Salivary Mucoepidermoid Carcinoma: Revisited. Adv Anat Pathol. 2006;13:293-307.

4. Neville BW, Damm DD, Allen CM, Bouquot JE. Oral and maxillofacial pathology; Salivary gland pathology, Fourth Edition, Saunders, USA (2016).

5. Seethala RR, Hoschar AP, Bennett A. Reproducibility of grading in salivary gland mucoepidermoid carcinoma and correlation with outcome: does system really matter? Mod Pathol. 2008; 21(1):241A.

6. Seethala RR. Histologic Grading and Prognostic Biomarkers in Salivary Gland Carcinomas. Adv Anat Pathol. 2011;18:29-45.

7. Auclair PL, Goode RK, Ellis GL. Mucoepidermoid Carcinoma of Intraoral Salivary Glands Evaluation and Application of Grading Criteria in 143 Cases. Cancer $1992 ; 69(8): 2021-30$.

8. Goode RK, Auclair PL, Ellis GL. Mucoepidermoid carcinoma of the major salivary glands: clinical and histopathologic analysis of 234 cases with evaluation of grading criteria. Cancer. 1998; 82(7):1217-24.

9. Brandwein MS, Ivanov K, Wallace DI. Mucoepidermoid carcinoma: a clinicopathologic study 
of 80 patients with special reference to histological grading. Am J Surg Pathol 2001;25 (2): 835-45.

10. Gnepp D, Allen CM, Bouquot JE, Eveson J. Diagnostic surgical pathology. 2nd edition, Saunders, an imprint of Elsevier Inc. USA, 2009.

11. Katabi A, Ghossein R, Ali S, Dogan S, Klimstra D, Ganly I. Prognostic features in mucoepidermoid carcinoma of major salivary glands with emphasis on tumour histologic grading. Histopath. 2014; 65, 793 804.

12. Nance MA, Seethala RR, Wang Y. Treatment and survival outcomes based on histologic grading in patients with head and neck mucoepidermoid carcinoma. Cancer 2008; 113; 2082-89.

13. Aro K, Leivo I, Makitie AA. Management and outcome of patients with mucoepidermoid carcinoma of major salivary gland origin: a single institution's 30-year experience. Laryng. 2008; (118)1: 258-62.

14. Speight, Barret. Salivary gland tumors. Oral Dis. 2002;8;229-40.

15. Vedrine PO, Coffinet L, Temam S, Montagne K, Lapeyre M, Oberlin O, Orbach D, Simon C, et al. Mucoepidermoid carcinoma of salivary glands in the pediatric age group: 18 clinical cases, including 11 second malignant neoplasms. Head Neck. 2006; 28:827-33.

16. Rapidis AD, Givalos N, Gakiopoulou H, Stavrianos $\mathrm{SD}$, Faratzis G, Lagogiannis GA, Katsilieris I. Patsouris E. Mucoepidermoid carcinoma of the salivary glands. Review of the literature and clinicopathological analysis of 18 patients. Oral Oncol. 2007; 43:130-36.

17. Schwarz S, Stiegler C, Muller M, Ettl T, Brockhoff G, Zenk J, Agaimy A. Salivary gland mucoepidermoid carcinoma is a clinically, morphologically and genetically heterogeneous entity: a clinicopathological study of 40 cases with emphasis on grading, histological variants and presence of the $t(11 ; 19)$ translocation. Histopath. 2011;58:557-70.

18. Janet O, Canales G, Morales-Vadillo R, Guillermo Guzmn-Arias, Carlos E, Cava-Vergiu, Guerra-Miller H, Jaime E. Montes-Gil. Mucoepidemoid carcinoma of the salivary gland. A retrospective study of 51 cases and review of the literature. Acta Odontol Latinoam. 2016; 29 (3):230-38.

19. Al-Azzawi L, Ghazi O, Hussein W. Immunohistochemical expression of Cyclin D1 in mucoepidermoid and adenoid cystic carcinoma of the salivary glands. J Bagh Coll Dentistry. 2015;27(3):649.

20. Ahmed O, Al-Azzawi L. MTA1 Expression in Salivary Mucoepidermoid Carcinoma: with Special Emphasis on Grading Systems. Journal of International Dent Med Res. 2019;12(4): 1253-57.

21. Barnes L. Diseases of the Salivary Glands. Surgical pathology of the head and neck.3rd edition, New York, informa, USA 2009, 475-648.

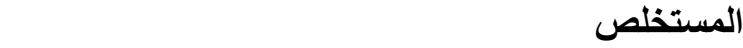
الخلفية : يعتبر السرطان المخاطي الحرشفي احد اكثر الانواع شيو عا بين اورام الغدد اللعابية الخبيثة والذي يتكون نسيجيا من خليط غير

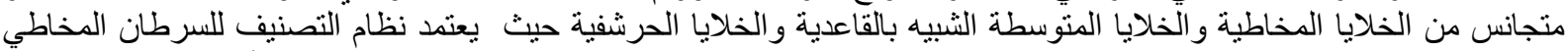
الحرشفي للغدد اللعابية على خصائص نسيجية وشكلية مختلفة . و الهدف من هذه الدراسة هو المقارنة بين نظامي أوكليروبر اندوين طبقا

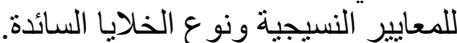

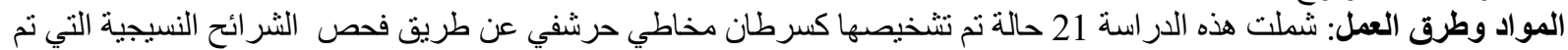

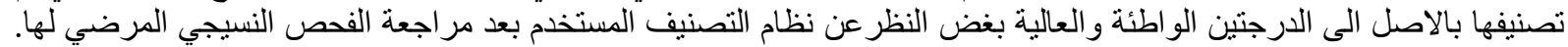
بعد ذلك تم تصنيف العينة طبقا للمعايير الخاصة بنظامي التصنيف أوكلير وبر اندوين. تم تحديد نوع الخلايا السائدة بواسطة التشخيص

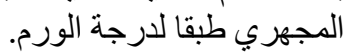
النتائج: أظهرت نتائج الفحص الورن المجهري حسب نظام أوكلير أن 10حالات (47.6\%) كانت ذات درجة و اطنئة و 11حالة (52.2\%)

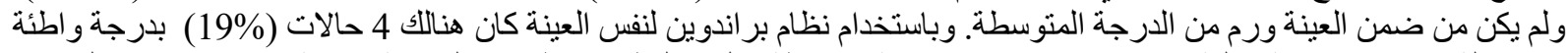

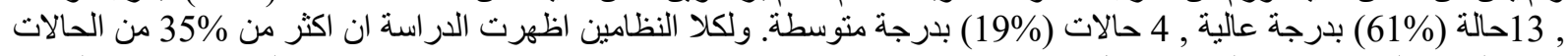

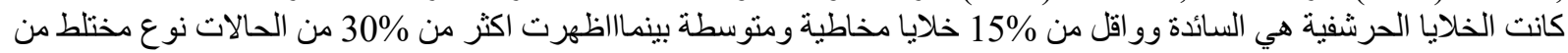

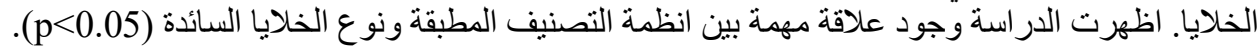

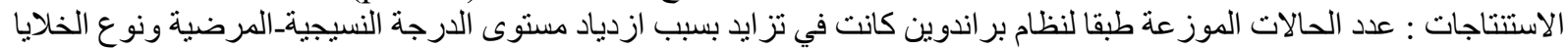

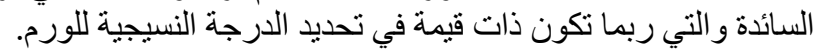

